\title{
Comparative Anatomy and Histology of Digestive Organs of Fruit-Eating Bats (Pteropus Vampyrus Linnaeus, 1758) and Insect-Eating Bats (Rhinolopus pusillus Temminck, 1834)
}

\author{
Desi Arsita Yani*, Wanda Nurma Yuliyantika \\ Biology Department, Faculty of Science and Technology UIN Sunan Kalijaga \\ Jl. Marsda Adisucipto No 1 Yogyakarta 55281, Indonesia. Tel. +62-274-540971, Fax. +62-274-519739 \\ *Email: desiarsita82@yahoo.co.id
}

\begin{abstract}
Animal Bat consists of Megachiroptera and Microchiroptera. The difference between the two bats lies in the type and behavior of eating. Megachiroptera is a fruit-eating bat, while Microchiroptera is an insect-eating bat. This study aims to compare the digestive organ of fruit-eating bats (Pteropus vampyrus) and insect-eating bats (Rhinolopus pusillus). This research was conducted by observing macroanatomy and microanatomy in the digestive organ of both bats. Macroanatomy observation is done by looking at the shape and curvature of the analysis through organ photo media. Microanatomy observation was done by making organ preparations with hematoxylin-eosin staining and observed using a microscope. The digestive organ of fruit-eating bats and insectivores consists of the esophagus, stomach, duodenum and rectum. Macroanatomically, fruit-eating bats and insectivores differ in size, where the fruit-eating bat's digestive organs are larger than insectivorous bats. Microanatomically, fruit-eating bats and insectivores have relatively similar histological structures, which differ only in the size of the cell.
\end{abstract}

Keywords: Anatomy, Digestive organ, Fruit-eating bat (Pteropus vampyrus), Histology, Insect-eating bat (Rhinolopus pusillus)

\section{INTRODUCTION}

Bats are active animals in the evening until night, besides that bats are the only mammals that can fly. Some types of bats rely on sharp senses of sight and smell to determine the direction of flight and foraging (Utzurrum, 1984). Fruit-eating bats use their sense of sight to recognize objects around them. Fruit-eating bats has a larger body size, big eyes, and fly higher (Suyanto, 2001). The uniqueness of the behavior of eating this type of bat is only absorbing the liquid contained in the fruit, so that the skin and seeds are only flattened and thrown away. This is what makes fruit-eating bats as one of the dispersing agents (Kingston et al., 2006).

Insect-eating bat use auditory ability (echolocation) to guide the direction of movement and seek prey. insect-eating bat has special characteristics of relatively smaller body size, small eyes, and flying is not too high (Suyanto, 2001). This type of bat uses its mouth to catch prey, then chews with its teeth (Hutson et al., 2001). Difference of fruit-eating and insect-eating bats is then felt necessary to be studied in order to compare the constituent tissues of the digestive and fruit-eating bat organs which include the esophagus, stomach, duodenum, rectum both anatomically and histologically.

\section{MATERIALS AND METHODS}

The materials used for this study were adult animal of fruit-eating bats (Pteropus vampyrus) and insectivorous bats (Rhinolopus pusillus). Anatomical observation were done by observing the topography, shape, and length of the digestive organs. Histological observation were done on histological slides stained with using Hematoxylin-Eosin (HE). Histological slides were made using paraffin method.

\section{RESULT AND DISCUSSION}

The digestive organs of fruit-eating and insect-eating bats have an arrangement that is generally the same as other mammals, which consist of the esophagus, stomach, pancreas, duoenum, large intestine, rectum. The stomach of the fruit-eating bat is located below the left diaphragm and is directly related to the duodenum. The shape of the stomach of the fruit-eating bat is shaped like the letter V (Figure1).

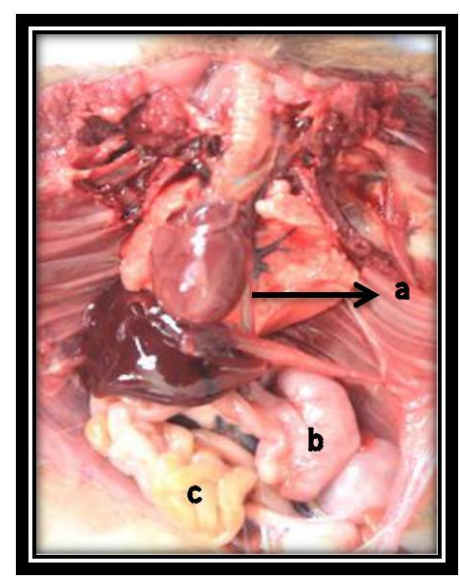

Figure 1. An overview of the anatomy of a fruit-eating bat. a. Esofagus, b. Gastric, c. Intestine. 
The digestive organs of the insect-eating bat is the same as the fruit-eating bat, the difference between these insect-eating bats is that the intestinal digestive tract is not winding and has a much shorter size than fruit-eating bats because the body size also affects the size of the anatomical organs of each species. Anatomically digestive organ of a fruit-eating bat and insect-eating bat can be seen in (Figure 1 and 2).

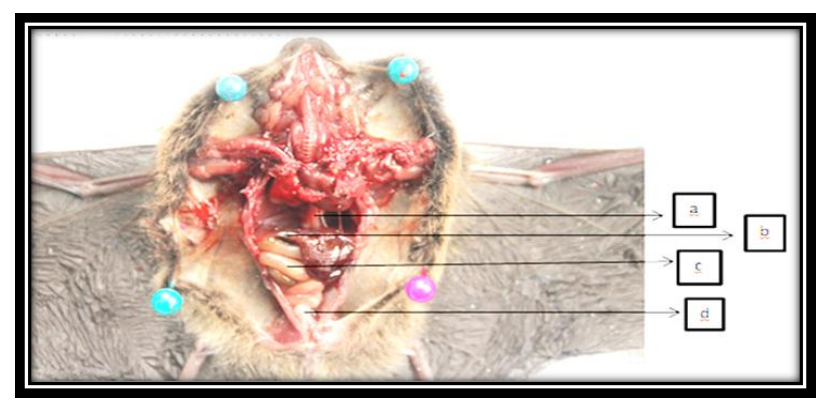

Figure 2. An Overview of the anatomy of an insect-eating bat. a Esofagus, b. Stomach, c. Duodenum, d. Rectum.

Table 1. Results of measurements of the length of the anatomical organs of fruit-eating bats and insect-eating bats.

\begin{tabular}{llllll}
\hline No & Animal & $\begin{array}{l}\text { Esofagus } \\
(\mathbf{c m})\end{array}$ & $\begin{array}{l}\text { Stomach } \\
(\mathbf{c m})\end{array}$ & $\begin{array}{l}\text { Duodenm } \\
(\mathbf{c m})\end{array}$ & $\begin{array}{l}\text { Rectum } \\
(\mathbf{c m})\end{array}$ \\
\hline 1 & $\begin{array}{l}\text { fruit-eating } \\
\text { bats }\end{array}$ & 3 & 4 & 30 & 15 \\
$2 \quad \begin{array}{l}\text { insect-eating } \\
\text { bats }\end{array}$ & 1 & 1 & 5 & 1,5 \\
\hline
\end{tabular}

Based on the results in Table 1, the size of the fruiteating anatomical bats with insect-eating bats has a different length. The size of the anatomical organs of fruit-eating bats tends to be longer than the anatomical organs of insect-eating bats. The digestive tract of the fruit-eating bats and insect-eating bats consists of the esophagus, stomach, duodenum, and rectum. Histologically, the digestive tract consists of several layers of walls, namely the mucosal layer, submucosal layer, and mucosal mucous layer.

Table 2. Comparison of histophotometry of fruit eaters and insectivorous bats.

\begin{tabular}{|c|c|c|c|}
\hline No & The part & $\begin{array}{l}\text { Fruit-eating } \\
\text { bats }\end{array}$ & $\begin{array}{l}\text { Insect- } \\
\text { eating bats }\end{array}$ \\
\hline & Esofagus & & \\
\hline 1 & Tunika Submukosa $(\mu \mathrm{m})$ & 131,4 & 150,5 \\
\hline 2 & $\begin{array}{l}\text { Tunika Muskularis } \\
\text { Mukosa }(\mu \mathrm{m})\end{array}$ & 54,4 & 57,2 \\
\hline 3 & Epitel $(\mu \mathrm{m})$ & 93,2 & 140,3 \\
\hline \multirow[t]{2}{*}{4} & Lumen $(\mu \mathrm{m})$ & 370,2 & 199,0 \\
\hline & Stomach & & \\
\hline 1 & Tunika Submukosa $(\mu \mathrm{m})$ & 118,1 & 136,4 \\
\hline 2 & $\begin{array}{l}\text { Tunika Muskularis } \\
\text { Mukosa }(\mu \mathrm{m})\end{array}$ & 54,1 & 214,6 \\
\hline & Duodenum & & \\
\hline 1 & $\begin{array}{l}\text { Tunika Muskularis } \\
\text { Mukosa }(\mu \mathrm{m})\end{array}$ & 253,3 & 57,2 \\
\hline 2 & Tunika Submukosa $(\mu \mathrm{m})$ & 82,9 & 11,8 \\
\hline \multirow[t]{2}{*}{3} & Serosa $(\mu \mathrm{m})$ & 56,5 & 15,3 \\
\hline & Rectum & & \\
\hline 1 & $\begin{array}{l}\text { Tunika Muskularis } \\
\text { Mukosa }(\mu \mathrm{m})\end{array}$ & 352,2 & 164,0 \\
\hline 2 & Serosa $(\mu \mathrm{m})$ & 108,7 & 88,5 \\
\hline
\end{tabular}

The fruit-eating bats and the insect-eating bats that were prepared with the paraffin method stained with Hematoxylin-Eosin (HE), had the same histological structure. The difference is seen in the size of the cell thickness found in the fruit-eating bats and the insecteating bats. Esophagus of fruit-eating bats and insecteating bats have a histological structure consisting of the muscularis mucosa, epithelium, lumen, lamina propria, and submucosa.
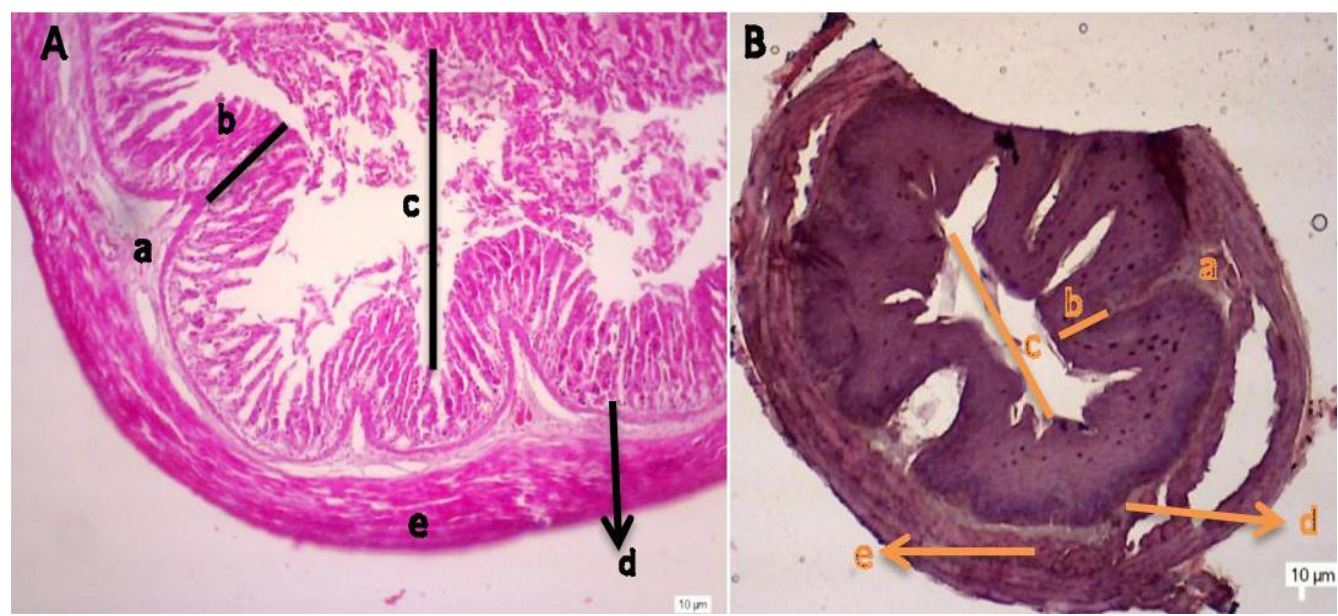

Figure 3. Esophageal histology. A. Eating bats, B. Insectivorous bats with HE coloring. 10x10 magnification: a. Sub-mucous layer, b. Epithelial layer, c. Lumen, d. Lamina propria layer, e. Muscularis mucosa. 
The stomach lining of the fruit-eating bats and insect-eating bats has the same histological structure, namely, the gastric mucosa consists of epithelium, lamina propria, and muscularis mucosa. Each of these bats has different cell structure sizes.

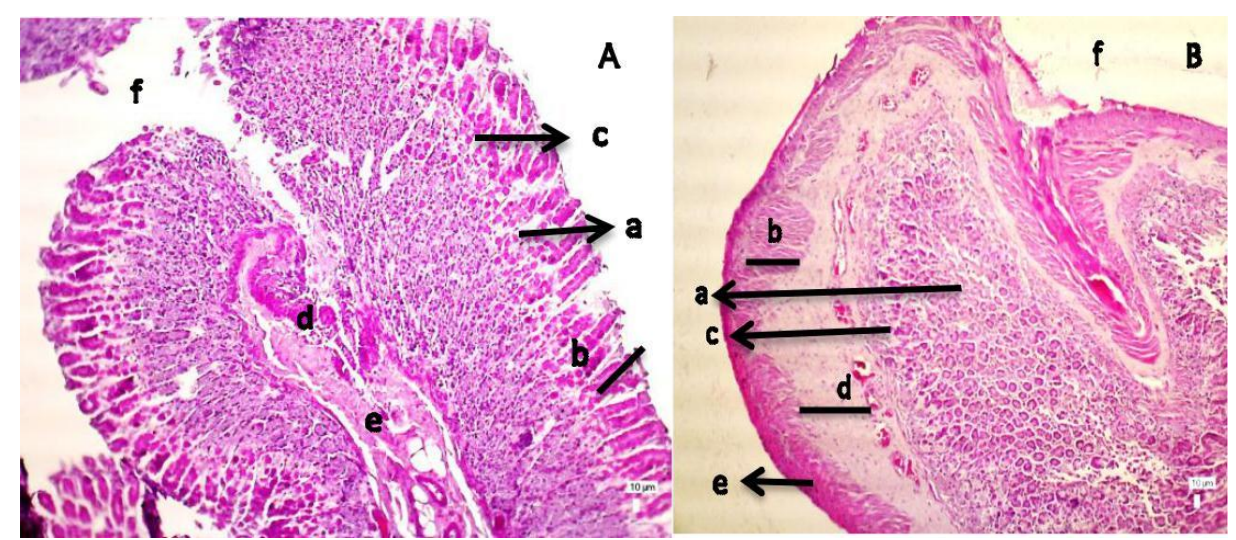

Figure 4. Histological features of the stomach. A. Fruit-eating bats, B. Insect-eating bats with HE coloring. 10x10 magnification: a. Sel zimogen b. Epithelium, c. Parietal cell d. Muscularis mucosal lining, e. Submucosal layer, f. Lumen.

The doudenum of fruit-eating bats and insect-eating bats, it is known that the doudoneum in both bats has a histological structure consisting of goblet cell, epithelium, lamina propria, the muscularis layer of mucosa,intestinal gland and villi.
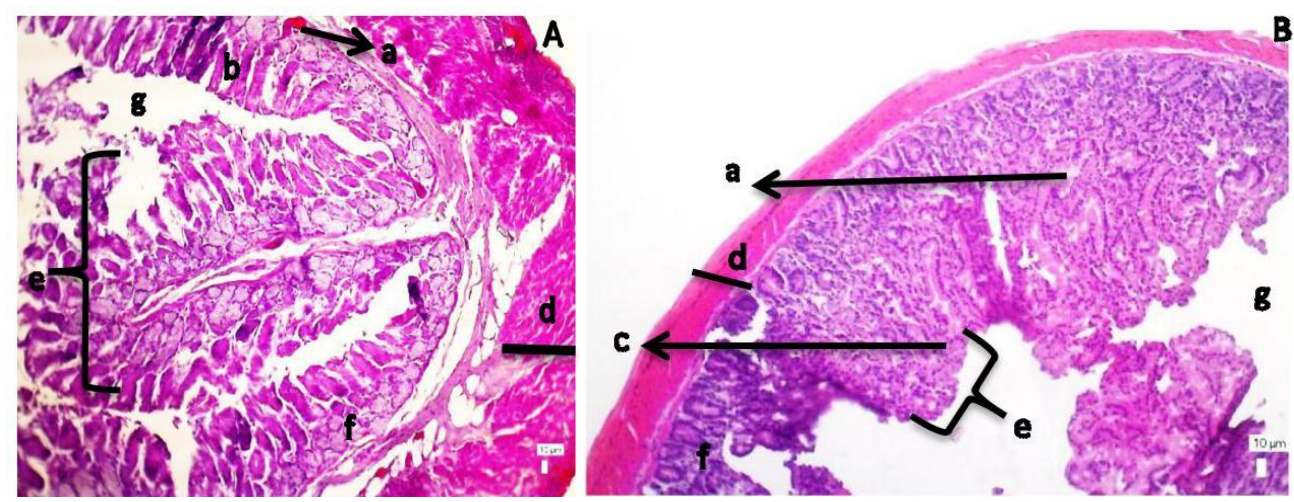

Figure 4. Histological features of the duodenum. A. Fruit-eating bats, B. Insect-eating bats with HE coloring. 10x10 magnification: a. Goblet cells, b. Epithelial layer, c. Layer of lamina propria, d. Muscularis mucosal layer, e.vili, f. Intestinal gland, g. Lumen.
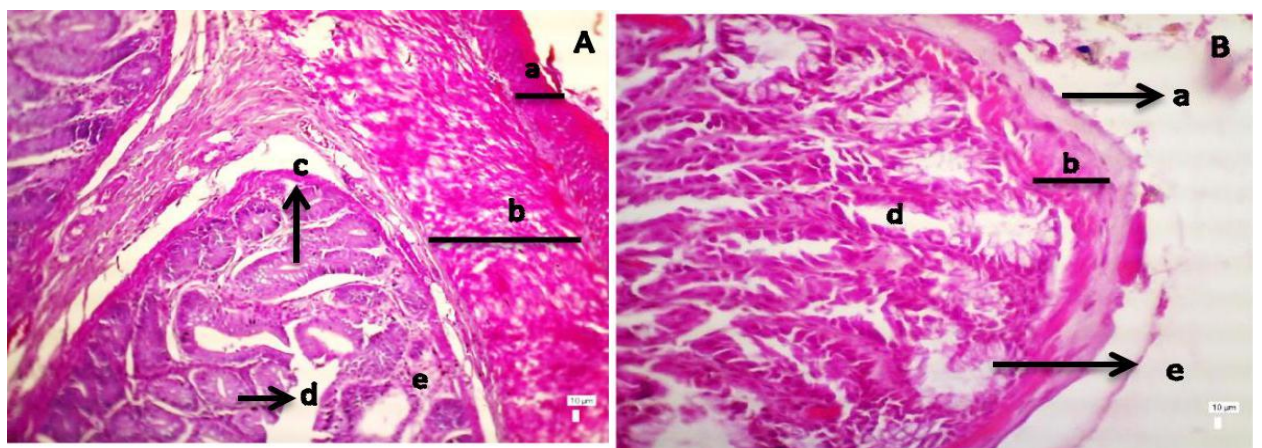

Figure 6. Histological features of the rectum. A. Fruit-eating bats, B. Insectivorous bats with HE coloring. 10x10 magnification: a. Serosa, b. Muscular mucosal layer, c. Kripta, d. Intestinal gland, e. Lamina propria. 
Based on observations in the rectum of fruit-eating bats and insect-eating bats, it is known that the rectum in both bats has a histological structure consisting of several layers, namely the muscularis layer of mucosa, submucosa, and serosa.

\section{CONCLUSIONS}

Based on the results of the study, we drew conclusion as follow:

1. Anatomically, digestive organ (esophagus, stomach, duodenum, and rectum) fruit-eating bat have bigger size than insect-eating bats.

2. Histologically, fruit-eating bat and insect-eating bats have relatively similar histological structures, but have a thickness of submucous tunica, muscularis, mucosa, serosa, lumen, and epithelium which are relatively different.

\section{ACKNOWLEDGMENTS}

The author would like to thank to the management of apprenticeship program of faculty of science and technology for guidance during the research, to the management of biology, medicine and natural product chemistry \& kaunia journal for assistance in paper writing.

\section{REFERENCES}

Hill, J. E., dan Smith, J. D. 1984. Bats: A Natural History, $1^{\text {st }}$ Ed British Museum (Natural History). P23.

Hutson, A., Mickleburgh, S.P dan Racey, P.A. 2001 Microchiropteran Bats: Global Status Survey and Conservation Action Plan. IUCN/SSC Chiroptera Specialist Group.

Kingston, T., Liem, B.L dan Akbar, Z. 2006. Bats of Krau Wildlife Reserve. Bangi: University Kebangsaan Malaysia. Hal 128.

Suyanto, A. 2001. Kelelawar di Indonesia. Bogor: Puslitbang Biologi-LIPI. Hal 59-

Utzurrum, R.C.B. 1984. Fig Fruit Composition and seed Dispersal by Frugivorous Bats in the Primary Tropical Rainforest of Lake Balinsasayo, Negros Oriental, Philippines. M.Sc thesis, Siliman University, Negros. 